\title{
Number and Distribution of Teats in Neomys fodiens
}

\author{
Iwona MICHALAK
}

Michalak I., 1986: Number and distribution of teats in Neomys fodiens. Acta theriol., 31, 9: 119-127 [With 5 Tables \& 2 Figs].

The study material consisted of 51 female Neomys fodiens (Pennant, 1771) caught in the Białowieża Primeval Forest and the Biebrza River Basin and 45 females of the same species born in captivity. The number of teats on both sides of the belly were: $5-5,5-6,6-6,6-7,7-7$. Most often the females had 12 teats $(71.9 \%)$. The distances between successive teats on one side of the belly differed in different females. It was only in $73.6 \%$ of the females that the teats were symmetrically distributed on the two sides of the belly. $40 \%$ of young females had a different number of teats from their mothers.

[Mammals Research Institute, Polish Academy of Sciences, 17-230 Białowieża, Poland].

\section{INTRODUCTION}

This study was undertaken in order to determine the degree of variation in the number of teats and their distribution in Neomys fodiens (Pennant, 1771) and to ascertain whether there are any regularities in number and distribution of teats in mothers and their daughters.

\section{MATERIAL AND METHODS}

The study material consisted of 48 live females of $N$. fodiens caught in the Białowieża Primeval Forest during the following years: $1980 \quad(n=1), 1981 \quad(n=2)$, $1983(n=45), 3$ females caught in the Biebrza River Basin in 1983 and 45 females born in captivity and originating from 11 litters from 11 females. Distribution of teats was determined only in 48 females caught in natural conditions and 23 females born in captivity.

The number and distribution of teats was defined in vivo by means of the so-called "teat spots" - the darker pigmentation of hair on the sites of the teats.

There was no difficulty in counting teats and making a plan of their distri. bution in the case of females born in captivity. The teat spots remain clearly visible through the whole period of nest development as the hair is clean and not matted. On the sixth day of life of young water shrews dark spots of pigment appear round the teats on the light-coloured, as yet hairless belly. During this period teats were counted only in case any of the young animals should died. The distribution plan of teats was made on the 14-20th day of the young animals' life, by which time it was possible to keep the animals outside the nest for a longer time. 
It was only in three females among those caught under field conditions that it proved impossible to define the number of teats. These three females had dark, almost melanistic bellies and it was very difficult to discern the teat spots. It was sometimes necessary to examine the belly of the same female twice or even three times in order to make a reliable distribution plan of teats. The skin of living animals held in the hand is unevenly stretched and it is sometimes impossible to avoid the consequent inaccuracy of estimate of distance between teats. In order to avoid being influenced by the first estimate, a repeat estimate was made several days later.

When distinguishing types of teat distribution their positions along each side of the belly were examined separately. The principle was adhered to that if the distance between two successive teats on one side of the belly was clearly lesser or greater than the distance between other adjacent teats, then this character was considered as distinguishing the given type of teat distribution. If differences in

\section{5 teats}

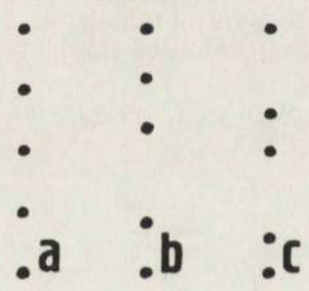

\section{6 teats}

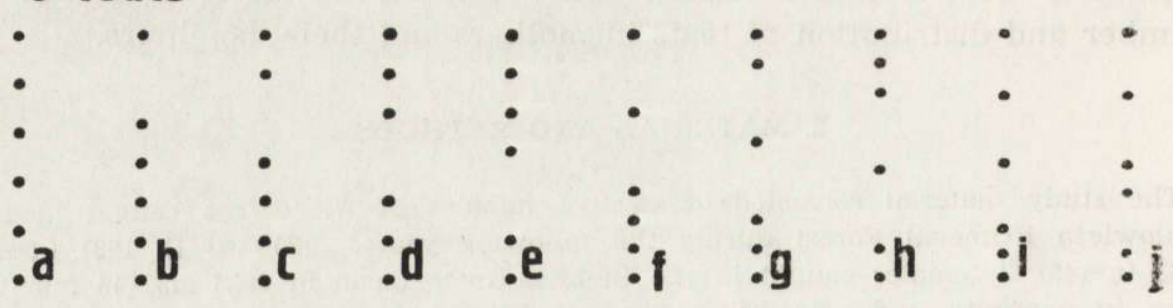

\section{7 teats}

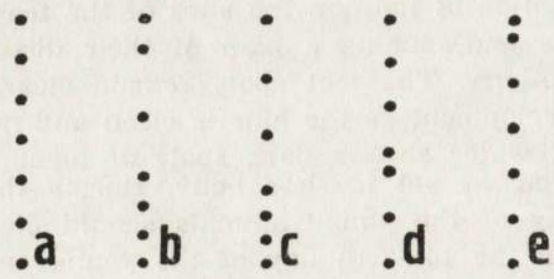

Fig. 1. Types of teat distribution on one side of the belly with occurrence of 5 , 6 and 7 teats. 
distances between successive teats were described in the card index as small, then this information was omitted and it was taken that the teats were evenly distributed.

On account of the very great diversity of teat distribution (Fig. 1) one further simplification was accepted. If the character differentiating the given type of teat distribution was, e.g. a considerable distance between the 4 th and 5 th and 5th and 6th teat, with simultaneous closely distributed remaining teats, then cases where distances between $4-5$ and $5-6$ were equal or unequal, were allocated to this type.

\section{RESULTS}

\subsection{Number of Teats}

The number of teats in $N$. fodiens varied from 10 to 14 . The following combinations of number of teats occurred: (1) 5 teats on each side of the belly, (2) 5 on one side and 6 on the other, (3) 6 on each side, (4) 6 on one side and 7 on the other, (5) 7 on each side.

Females with 12 teats occurred most frequently in the whole of the study material $(71.9 \%)$. The frequencies of females with a smaller or larger number of teats were similar, respectively $13.5 \%$ and $14.6 \%$ a. (Table 1).

\section{Table 1}

Frequency of occurrence of a varying number of teats in female $N$. fodiens.

\begin{tabular}{|c|c|c|c|c|c|c|}
\hline \multirow{2}{*}{$\begin{array}{c}\text { Number } \\
\text { of } \\
\text { teats }\end{array}$} & \multicolumn{2}{|c|}{$\begin{array}{l}\text { Born in } \\
\text { captivity }\end{array}$} & \multicolumn{2}{|c|}{$\begin{array}{l}\text { Caught } \\
\text { in field } \\
\text { conditions }\end{array}$} & \multicolumn{2}{|c|}{ All } \\
\hline & $\mathrm{n}$ & $\%$ & & $\%$ & $\mathrm{n}$ & $\%$ \\
\hline 10 & 3 & 6.7 & 1 & 2.0 & 4 & 4.2 \\
\hline 11 & 3 & 6.7 & 6 & 11.8 & 9 & 9.4 \\
\hline 12 & 32 & 71.1 & 37 & 72.5 & 69 & 71.9 \\
\hline 13 & 7 & 15.6 & 5 & 9.8 & 12 & 12.5 \\
\hline 14 & 0 & 0 & 2 & 3.9 & 2 & 2.1 \\
\hline
\end{tabular}

Frequencies of occurrence of different categories of teat numbers in: females caught under field conditions or born in captivity did not differ significantly (chi-square test, $p>0.5$ ).

\subsection{Distribution of Teats}

Two questions were taken into consideration: (1) types of distribution: of teats on one side of the belly for 5,6 and 7 teats, (2) symmetry of distribution of teats on both sides of the belly in females having an even number of teats. 
3.2.1. Females with an Even Number of Teats

For 48 females with 12 teats 10 types of distribution of teats were distinguished, considering each side of the belly separately (Fig. 1). Frequency of occurrence of different types of distribution of 6 teats is given in Table 2). The way in which teats were distributed on one side of the belly did not always correspond on the type of teat distribution on the other side of the belly (Table 3). Symmetrical distribution of teats on both sides of the belly occurred in $70.8 \%$ of the females examined.

\section{Table 2}

Frequency of occurrence of different types of teat distribution.

Each side of the belly has been considered separately. Symbols of types of teat distribution as in Fig. 1.

\begin{tabular}{|c|c|c|c|c|c|c|c|c|c|c|c|}
\hline $\begin{array}{l}\text { Number of teats } \\
\text { on one side of } \\
\text { belly }\end{array}$ & $\begin{array}{c}n \\
\text { of sides } \\
\text { examined }\end{array}$ & a & b & $\begin{array}{c}\text { Types } \\
\text { c }\end{array}$ & $\begin{array}{l}\text { of } \\
\text { d }\end{array}$ & $\begin{array}{c}\text { teat } \\
\mathrm{e}\end{array}$ & $\begin{array}{l}\text { dist } \\
\mathrm{f}\end{array}$ & ibu & $\begin{array}{c}\text { tion } \\
\mathrm{h}\end{array}$ & i & $j$ \\
\hline 5 & 14 & 12 & 1 & 1 & & & & & & & \\
\hline 6 & 96 & 19 & 7 & 3 & 1 & 1 & 26 & 3 & 1 & 31 & 4 \\
\hline 7 & 12 & 1 & 6 & 2 & 1 & 2 & & & & & \\
\hline
\end{tabular}

Table 3

Comparison of distribution of teats on either side of the belly in females with 6-6 number of teats. Types of teat distribution on right side of belly (R) shown in horizontal line, on left side of belly (L) in vertical line. Symboles of types of teat distribution as in Fig. 1, for side of belly with 6 teats.

\begin{tabular}{|c|c|c|c|c|c|c|c|c|c|c|c|c|}
\hline L & $\mathrm{R}$ & a & b & c & d & e & $f$ & g & $\mathrm{h}$ & $\mathrm{i}$ & $j$ & $\mathrm{n}$ \\
\hline a & & 6 & - & - & - & - & 1 & - & 1 & 1 & 1 & 10 \\
\hline b & & $\overline{1}$ & 3 & - & 1 & - & - & - & - & - & - & 4 \\
\hline $\begin{array}{l}\mathrm{c} \\
\mathrm{d}\end{array}$ & & 1 & E & 1 & + & - & - & - & - & - & - & 2 \\
\hline $\mathrm{e}$ & & $\overline{1}$ & $\overline{-}$ & $\overline{-}$ & $\bar{z}$ & $\bar{z}$ & $\bar{z}$ & $\bar{E}$ & $\bar{z}$ & $\bar{z}$ & Z & 0 \\
\hline$f$ & & - & - & - & - & - & 10 & - & - & 1 & 1 & $\begin{array}{r}1 \\
12\end{array}$ \\
\hline g & & - & - & - & - & - & - & 1 & - & 1 & - & 2 \\
\hline$\underline{h}$ & & - & - & - & - & - & - & - & - & - & - & 0 \\
\hline $\mathrm{i}$ & & 1 & - & - & - & - & 3 & - & - & 12 & - & 16 \\
\hline$j$ & & - & - & - & - & - & - & - & - & - & 1 & 1 \\
\hline $\mathrm{n}$ & & 9 & 3 & 1 & 1 & 0 & 14 & 1 & 1 & 15 & 3 & 48 \\
\hline
\end{tabular}

In the three females with 10 teats only one type of distribution of 5 teats occurred, i.e. distances between teats on one side of the belly were more or less equal (Fig. 1, type 5a), and consequently the distribution of teats on both sides of the belly was reciprocally symmetrical. Sim- 
ilarly in the case of two females with 14 teats symmetry was maintained on both sides of the belly and the teats were distributed according to one type (Fig. 1, type $7 \mathrm{~b}$ ).

\subsubsection{Females with an Uneven Number of Teats}

In females with 11 or 13 teats there was no new type of distribution of 6 teats on one side of the belly which had not been found in females with 12 teats. Distribution of 5 teats on the other side of the belly constituted three types, the distribution described in females with 10 teats predominating (six females out of eight) (Fig. 1, Table 2). The type of distribution of 7 teats found in females with 14 teats occurred in two females out of eight with 13 teats (Fig. 1, Table 2).

\subsubsection{Number and Distribution of Teats in Litters}

It was only in $60.0 \%$ of young females that the number of teats agreed with the number of teats in their mothers (treating the material as a whole) (Table 4). Within one litter a maximum of three different types of combinations of teat number occurred. At least one female in each litter had a different number of teats from its mother.

Table 4

Number of teats in young females and in their mothers.

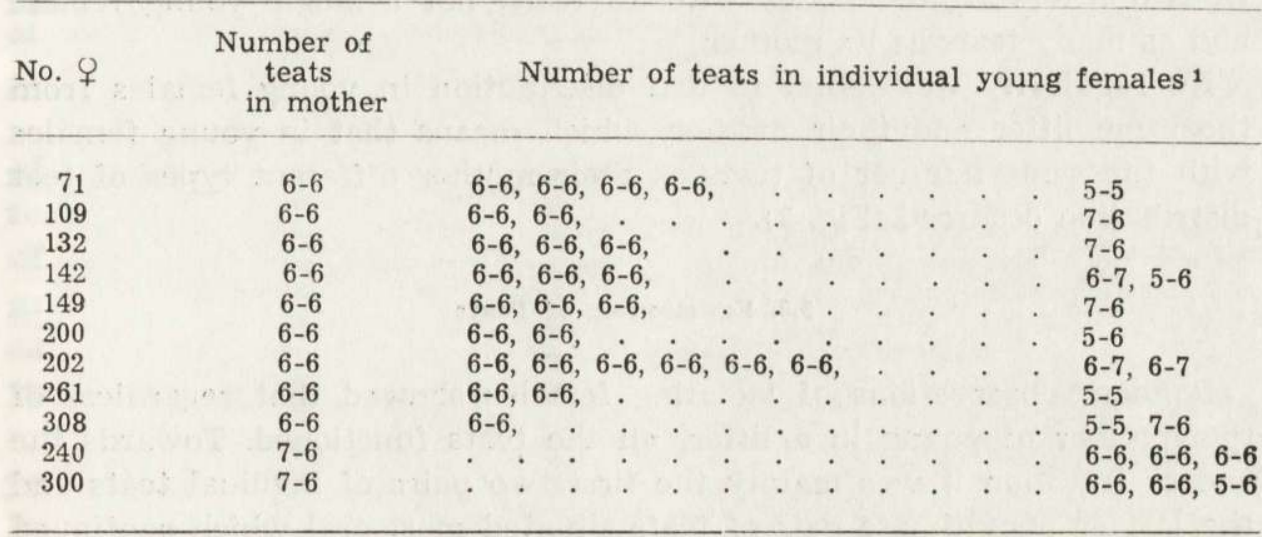

1 On right side females with a different number of teats from their mother. 
mothers
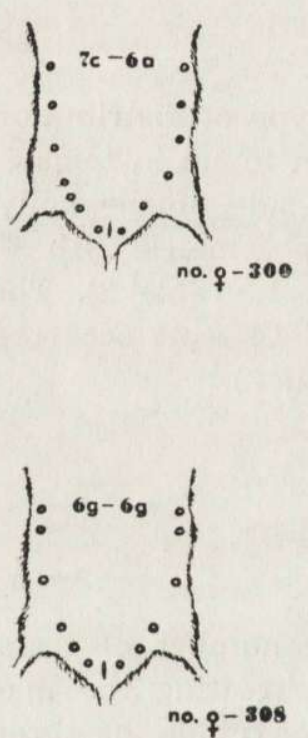

young females
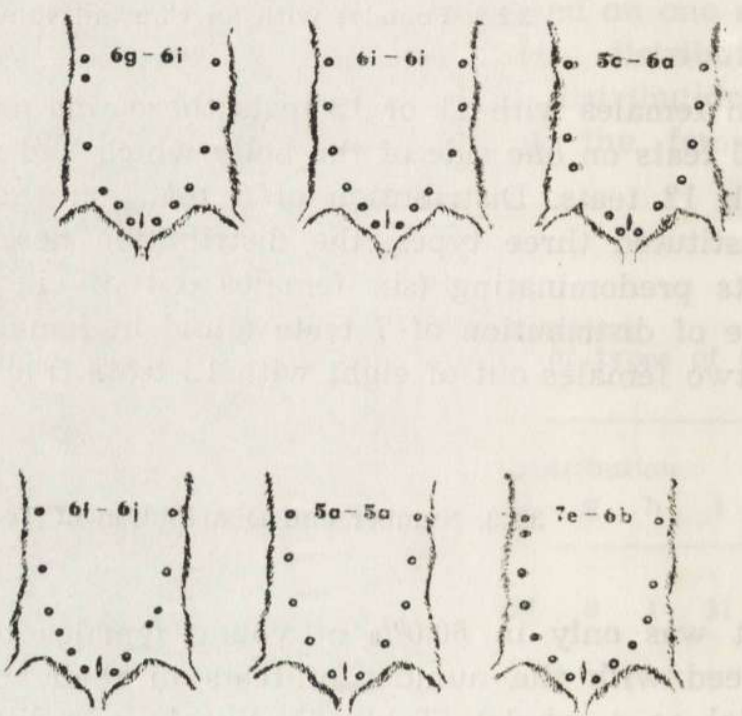

Fig. 2. Variations in number and distribution of teats in mothers and young females, using two litters as examples.

In two litters from females with 13 teats, not a single young female had as many teats as its mother.

No regularity was found in teat distribution in young females from the same litter and their mother, which means that in young females. with the same number of teats as their mother different types of teat distribution occurred (Fig. 2).

\subsection{Functioning of Teats}

Random observations of lactating females showed that regardless of the number of young in a litter, all the teats functioned. Towards the end of lactation it was mainly the first two pairs of inguinal teats and the last or penultimate pair of teats situated most oral which continued functioning. 


\section{DISCUSSION}

A review of data in literature so far published on the number of teats in Soricidae shows that three pairs of teats form a constant number in almost all shrews examined, with the exception of the genus Neomys. The first data on the large number of teats in Neomys fodiens and Neomys anomalus Cabrera, 1907 were published by Bauer (1960) and Niethammer (1977). Both authors, although having only scanty material at their disposal, were able to state that the number of teats in Neomys is of a variable character (Table 5).

Table 5

Variations in number of teats on either side of the belly in Neomys fodiens and Neomys anomalus.

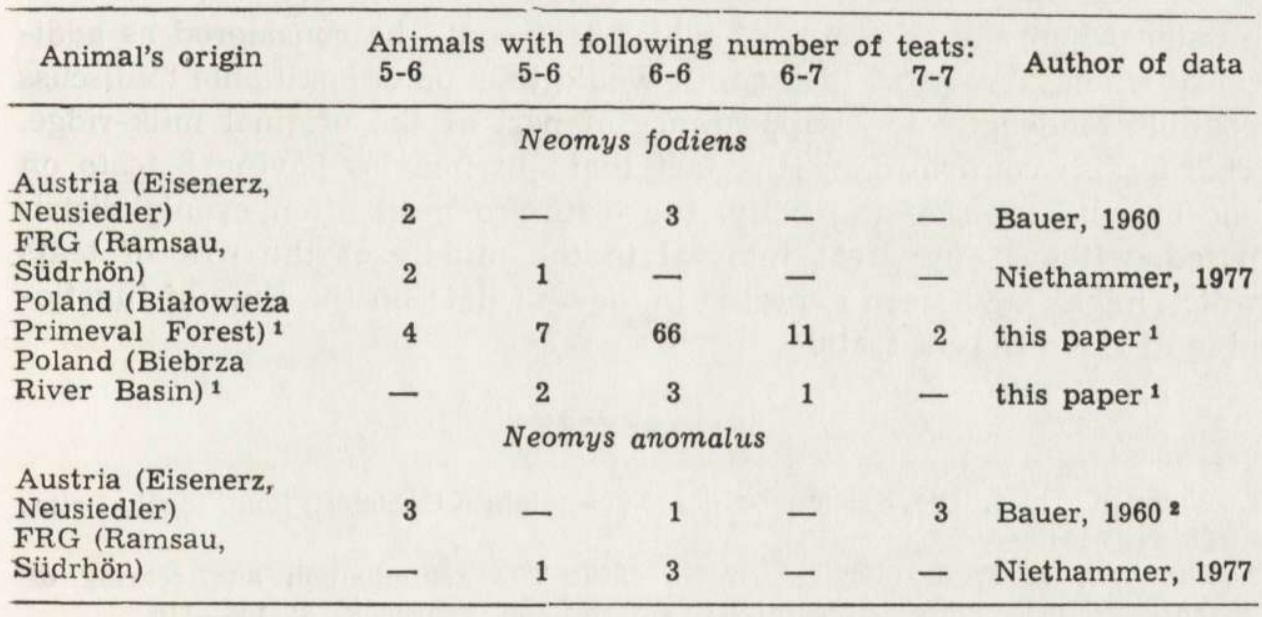

1 Data refer only to animals caught under field conditions, 2 One female with 20 teats (10 in a double row on either side of the belly) found by Bauer (1960) at Eisenerz has been omitted from the table.

Within the order Insectivora Neomys takes second place in order of number of teats. Tenrec has far more than Neomys, i.e. 12 pairs of teats. Setifer and Erinaceus have one pair less than Neomys i.e. 5 pairs of teats. In Tenrec this large number of teats is connected with the very great fertility of this animal, the litter of which may contain as many as 32 young (Eisenberg \& Muckenhirn, 1968). In the case of Neomys it is impossible to give an unequivocal reply to the question as to whether the large number of teats corresponds to the large numbers of young in a litter in comparison with other representatives of Soricidae. From comparison of average number of young in a litters in Soricidae it would not appear that Neomys had the highest values (cf. Michalak 
1983, literature data of fertility of $N$. fodiens). Maximum litter sizes: of $N$. fodiens 14 (Stroganow, 1957), and 15 (Michalak, 1983) and of $N$. anomalus 12 (Michalak, unpublished) and 13 (Krapp, 1974) are in fact the highest values of this kind in Soricidae, but these data cannot form a sufficient argument in this matter. A reliable solution of the above questions would be rather to compare data on the subject of the number of young reared in different species of shrew. Unfortunately there are no such data. The ability of Neomys fodiens in this respect is shown by the example of a female kept in captivity, which reared the whole of its litter of 11 young (Michalak, unpublished).

Data on variation in the number of teats and their distribution in $N$. fodiens do not permit of reaching any conclusions as to the evolution of these characters. With the very great diversity of distribution of 6 teats on one side of the belly it is impossible to say which teat is missing when only 5 occur, or which teat could be considered as additional when there are 7 of them. It would thus be unjustifiable to discuss possible tendencies to disappearance of part of the original milk-ridge. This is also confirmed by the fact that in females having 5 teats on one or both sides of the belly, the teats are most often evenly distributed, without any great interval in the middle of the row of teats which might have been expected in view of data on the time of functioning of the different teats.

\section{REFERENCES}

1. Bauer K., 1960: Die Säugetiere des Neusiedlersee-Gebietes. Bonn. zool. Beitr., 11: $141-344$.

2. Eisenberg J. F. \& Muckenhirn N., 1968: The reproduction and rearing of tenrecoid insectivores in captivity. Intern. Zoo Yearbook, 8: 106-110.

3. Krapp F., 1974: Hohe Embryonenzahl auch bei Neomys anomalus milleri (Mottaz, 1907). Z. Säugetierk., 39: 201-203.

4. Niethammer J. von, 1977: Ein syntopes Vorkommen der Wasserspitzmäuse Neomys fodiens und $N$. anomalus. Z. Säugetierk., 42: 1-6.

5. Michalak I., 1983: Reproduction, maternal and social behaviour of the European water shrew under laboratory conditions. Acta theriol., 28: 3-24.

6. Stroganov S. U., 1957: Zveri Sibiri. Nasekomojadnye. Akad. Nauk SSSR: 1-267. Moskva.

Accepted, June 13, 1985. 


\section{I wona MICHALAK}

\section{LICZBA I ROZMIESZCZENIE SUTEK U NEOMYS FODIENS}

\section{Streszczenie}

Zbadano zmienność liczby i rozmieszczenia sutek u 48 samic Neomys fodiens: (Pennant, 1771) odłowionych w Puszczy Białowieskiej i trzech samic $z$ doliny Biebrzy oraz u 45 samic urodzonych $w$ hodowli laboratoryjnej.

Liczba sutek wynosiła po obu stronach brzucha: 5-5, 5-6, 6-6, 6-7, 7-7. Najczęściej samice posiadały 6-6 sutek (71.9\%), przy czym frekwencje samic z mniejszą i większą niż 12 liczbą sutek były do siebie zbliżone (odpowiednio: 13.5 i $14.6 \%$ ).

$\mathrm{U}$ młodych samic urodzonych $\mathrm{w}$ hodowli liczba sutek $\mathrm{w} 40.0 \%$ nie zgadzała się z liczbą sutek u ich matek. W obrębie jednego miotu występowały maksymalne trzy kombinacje liczby sutek (Ryc. 2, Tabela 4).

Typy rozmieszczenia sutek oraz frekwencje ich występowania przedstawiono na Ryc. 1 i w Tabeli 2. Symetryczny układ sutek obu stron brzucha występował u $70.8 \%$ samic posiadających parzystą liczbę sutek.

W obrębie rzędu Insectivora Neomys fodiens i $N$. anomalus znajdują się na drugim miejscu pod względem liczby sutek. Jedynie Tenrec posiada aż 12 par sutek. Wśród Soricidae rodzaj Neomys stanowi wyjątek, gdyż pozostałe ryjówki mają po trzy pary sutek. 